\title{
Constipation during and after pregnancy. (Mini-commentary on BJOG-20-0822.R1)
}

\author{
Rufus Cartwright $^{1}$ and Hege Johannessen ${ }^{2}$ \\ ${ }^{1}$ Imperial College London \\ ${ }^{2} \emptyset$ stfold Hospital Trust
}

November 9, 2020

\section{Hosted file}

20-2268 MC formatted.pdf available at https://authorea.com/users/328559/articles/491789constipation-during-and-after-pregnancy-mini-commentary-on-bjog-20-0822-r1 